\title{
A NEW TURN IN THE PRIVATIZATION POLICY
}

\author{
G.Malginov, A.Radygin
}

The Forecast Plan (Program) for the Privatization of Federal Property and the Main Guidelines for the Privatization of Federal Property in 2014-2016 were approved by the Russian Government's Executive Order dated JuIy 1, 2013, No. 1111-r. This is already a second 3-year privatization program developed with consideration for the planning period of the Forecast Plan (Program) for the Privatization of Federal Property (from one year to three years) based on the amendments which were made to the applicable law on privatization in the spring of 2010.

The structurally approved privatization program contains two sections, as before. The first one contains main government's directives, forecasts of the effect which privatization might have on structural changes in the economy, including plans of privatization of the largest companies leading in respective industries and volumes of federal budget revenues generated from sale of federal property. The second one contains a list of property items to be privatized under a normal procedure (514 SUEs (state unitary enterprises), 436 JSCs, 4 CJSCs and 94 other Russian Federation Treasury's property items) similar to the procedure which have been employed over the past few years.

However, the new privatization program differs largely from the previous program for 2011-2013 which was adopted in November 2010.

First, unlike all the privatization programs which have been released since $2002^{1}$, the new program contains no explicitly formulated objectives of the national privatization policy.

As a substitute for such objectives there is a reference to basically the Presidential Decree dated May 7, 2012, No. 596 "On the Long-Term National Economic Policy" rather than the objectives and goals provided for by the "Federal Property Management" National Program of the Russian Federation approved by the Russian Government Executive Order dated February 16, 2013, No. 191-r (without any specification). It is envisaged in the Decree that until 2016 the state is to cease to held interest in companies involved in the non-mineral sector which are not regarded as entities of natural monopolies and defense industry, and also there is a reference in the context of the document to

1 It is to recall that the previous program for privatization in 2011-2013 provided for the following objectives. Create conditions enabling one to encourage extra budgetary investments for the development of joint-stock companies based on new technologies; shrink the public sector of the economy with a view to enhancing and encouraging private investors' initiatives; enhance corporate governance; provide incentives for the development of the stock market; establish integrated entities in strategically important industries; generate federal budget revenues.
Subparagraph " $c$ ", Paragraph 1 in which the government is commissioned to take measures aimed at increasing by 1.3 times against 2011 (among other indicators) the share of products of high-tech and knowledge intensive industries in the gross domestic product by 2018.

Such reference has caused raised eyebrows, because the instructions on the enhancement of privatization and management of state-owned property for the government are set forth in subparagraph " $\mathrm{C}$ ", Clause 2 (not Clause 1) of the Presidential Decree dated May 7, 2012, No. 596. Unless it's just a simple inaccuracy, the new privatization program fails to show any relations between sale of different state-owned assets and growth in the output of high-tech and knowledge intensive products.

With regard to the content of the document, it should be noted that it contains additional exclusions: (1) joint-stock companies and enterprises which are included into the list of strategically important organizations, (2) minority state-held interest in JSCs which are subsidiaries of the parent companies of vertically-integrated entities for the purpose of their further contribution to the charter capital of parent companies of respective integrated entities, as well as (3) a federally-held 'single' interest in JSCs on which budget expenditures on the preparation of privatization exceed the amount of potential federal budget revenues.

Second, in the forecast of the effect of property privatization on structural changes in the economy quantitative breakdown of economic agents which pertain to state property and are subject to privatization was presented for the first time in terms of type of economic activity rather than industries. In this context one may say that about belated harmonization of the contents of privatization programs with the classification employed in statistic reports as early as since 2005 , which was repeatedly pointed out by the Accounts Chamber of the Russian Federation. A negative aspect of such a change is that it is impossible to make a correct comparison of the structure of economic agents which are regarded as federal property. One only may assert that their 
quantity has just been reduced over the three years between January 1, 2010 and January 1, 2013: FSUEs (federal state unitary enterprises) were almost halved (from 3517 to 1795), while federally-owned JSCs were reduced by more than 1/5 times (from 2950 to 2337).

However, like in the previous privatization program, the forecast of the effect of privatization on structural changes in the economy has been performed as a mere formality, because it fails to even provide a general assessment of anticipated changes in the share held by the public sector, let alone the effect of privatization on the dynamics of output, employment, investments and innovations, budget load size relating to stateowned property, tax compliance status, etc.

Third, plans for privatization of major companies have undergone serious changes against the way this process was specified by the Russian Government Executive Order dated June 20, 2012, No. 1035-r in the current privatization program for 2011-2013.

With regard to the list of assets suggested for privatization, it has remained unchanged in general, with Rosagroleasing, Russian Agricultural Bank (it was previously stated that the state would cease to hold its interest in these entities until 2016) and FGC UES (Federal Grid Company of Unified Energy System) (a state-held interest in this entity was envisaged to shrink down to $75 \%$ plus one share) having been removed from the list, whereas ROSNANO (a state-held interest was expected to shrink down to $90 \%$ through fresh issue and placement of shares), Rosspirtprom, Rostelecom and the State Transport Leasing Company having been added to the list.

However, unlike the privatization program for 2011-2013 in its version dated June 2012, the interest held by the Russian Federation in many largest companies is supposed to retain corporate control or at least makes it possible to influence the corporate governance procedure by holding a blocking interest (25\% plus one share).

The latter option is envisaged for ALROSA jointstock company (with coordination of sale of the interest held by the Republic of Sakha Yakutia and municipalities), Aeroflot Russian Airlines, Sovcomflot. What is meant hear is a state-held interest of $50 \%$ plus one share when it comes to Federal Hydrogeneration Company (RusHydro) and VTB Bank, whereas the state-held interest in JSC Zarubezhneft also might shrink down to the same value, but until 2020 (with an intermediate threshold of $90 \%$ until 2016). The previous privatization program envisaged that until 2016 the state would cease to hold its interest in all of the above listed companies subject to the execution of a special right for the Russian Federation in the management of joint-stock companies (golden share) with regard to JSC Zarubezhneft, RusHydro, Aeroflot and ALROSA.

The other group included such companies as Russian Railways, Oil Transporting Joint Stock Company "Transneft", UralVagonZavod Scientific Industrial Corporation in which the previous minimal possible stateheld interest (75\% plus one share) has been retained. The State Transport Leasing Company has been added to these companies.

Shrinkage of the interest held by the Russian Federation in the United Aircraft Corporation (UAC) and United Shipbuilding Corporation (USC) is to be extended to 2024, with the previous value of stateheld interest in the UAC (50\% plus one share) being retained, whereas the state-held interest in the USC being increased (up to $75 \%$ plus one share against previous $50 \%$ plus one share). In this context the idea of retaining a state-held interest of $0 \%$ plus 9 shares in INTER RAO UES is not quite clear, because it was previously stated that the state would cease to hold its interest until 2016 (the company is presently included into the list of strategic organizations).

A shrinkage down to $50 \%$ plus one share (previously it was stated that the state would cease to hold its interest before a specified period) of the interest held by OJSC ROSNEFTEGAZ in Rosneft oil company until 2016 stands apart from the key distinctions from the previous privatization program. Until 2015 OJSC ROSNEFTEGAZ still may act as investor in fuel and energy companies planned for privatization, provided that there is a program of financing of such transactions which provides for the use of dividends from companies' shares held by the foregoing joint-stock company.

With regard to a potential shrinkage (down to less than $50 \%$ plus one share) of the state-held interest in OJSC Bank VTB, the program specifies that it will be done with coordination of measures aimed at shrinking the state-held interest in OJSC Sberbank of Russia ${ }^{1}$, though the Chairwoman of the Central Bank of Russia asked to exclude from the text of the forecast privatization plan the items which concern potential changes in the state-held interest in banks after 2016, having said that the Central Bank has no plans to shrink the interest held by the Russian Federation in Sberbank.

It has been stated that in the years of 2014 thru 2016 the state would cease to hold its interest in seven companies, namely Rosspirtprom, Unified Grain Company (UGC), ROSNANO, Rostelecom, Sheremetyevo International Airport (SHIA), Vnukovo Airport, Vnukovo Inter-

1 According to the Ministry of Economic Development and Trade of Russia and the Federal Agency for State Property Management, VTB will be losing its competitive advantages if its state-held interest keeps shrinking and the state-held interest in Sberbank remains unchanged. 
national Airport, of which only the UGC and the SHIA were facing such a perspective until 2016 in the previous privatization program. Furthermore, Presidential and Russian Government's decisions on strategic development of the Moscow Air Transportation Cluster must be taken into account with regard to the three metropolitan airports. These and some other companies (UGC, ALROSA, Rostelecom) may exercise the special right of the Russian Federation to participate in the management of joint-stock companies (golden share).

It should be noted, however, that the cessation of a state-held interest in actually each of these companies is very likely to raise certain questions.

Basically, it refers to OJSC Rostelecom whose reorganization was approved, by a Presidential Decree in the spring of 2012, through acquisition of OJSC Investitsionnaya Kompaniya Svyazi (better known as Svyazinvest) and its removal from the list of strategic entities, provided that the state jointly with Vnesheconombank take control over more than 50\% Rostelecom common shares. However, by the beginning of the current year reorganization of the public segment of the telecommunication industry was only at the stage of Svyazinvest additional issue under which the state will transfer core assets (including the interest in Central Telegraph, Bashinformsvyaz and other companies) to the holding company. To retain its interest in Svyazinvest (25\% plus one share, the rest is held by the state), it is Rostelecom who must participate in financing of additional issue.

In this respect, it should be noted that sale of the federally-held interest in Svyazinvest used to be repeatedly rescheduled for various reasons, of which a set of social and regional issues (tariff reform, social load on its subsidiary and affiliated regional communication operators) prevailed along with reorganization and optimization of holding's corporate structure as early as the 2000s, as well as restrictions relating to national security (provision of communication services to power departments, protection of interests of special consumers of communication services). No practical mechanisms of solution of these problems with a new format of acquisition of Svyazinvest by Rostelecom have been disclosed to date.

With regard to ROSNANO, the issue of compensation for the previous budget expenditures spent on the asset contribution from this former state-owned corporation and the effectiveness of development institutions in general will logically come into focus; with regard to the UGC, the focus will be placed on the use of monies raised through a private subscription in 2012, as well as the storage of national grain reserves and participation in commodity and purchasing interventions; with regard to OJSC Rosspirtprom, the focus will be placed on ensuring control of the alcohol market amid a marked fall of legal sales of alcoholic beverages in response to raise in excises, and how budget generates revenues in general from this historically traditional source of revenues in Russia; with regard to the metropolitan airports, the focus will be placed on further budget financing for the purpose of their reconstruction and transparency of a new capital structure in view of the numerous problems which have been faced by the Domodedovo Airport since the mid-2000s ${ }^{1}$.

With regard to budget revenues from privatization, one may see a substantial reduction in volumes, net of the value of shares of largest companies leading in respective industries. In 2014-2016 such revenues are expected to amount to $\mathrm{Rb} 3 \mathrm{bn}$ annually against Rb 6bn in 2011, and Rb 5bn in 2012 and 2013 which were forecasted in the previous privatization program.

There is no forecast of principal revenues from privatization of the interest in largest companies which have very good investments prospects, in case the Russian Government takes certain decisions, whereas the previous privatization program specified an amount of Rb 1 trillion for a period of 2011-2013.

Furthermore, it has been mentioned that the President and the Russian Government might take decisions on privatization by shrinking the state-held interest in a company through additional issue and allocation of raised monies to recapitalize joint-stock companies with due regard to the aspects of long-term development and their investment needs required for implementing corporate development strategies, as well as capital adequacy requirements (with regard to banks).

If based on the information obtained from official sources following the results of the discussion of the Draft Forecast Plan for Privatization in 2014-2016 at Russia's Government meeting on June 27, 2013, one may talk about around $\mathrm{Rb} 630 \mathrm{bn}$ as direct budget revenues mainly from sale of shares of JSCs which are leading in specific industries over three years (Rb 180bn in 2014, Rb 140bn in 2015, and Rb 300bn in 2016), as well as, presumably, with due regard to $\mathrm{Rb} 9 \mathrm{bn}$ from other sales. Another $\mathrm{Rb} 380 \mathrm{bn}$ are supposed to be generated as dividends OJSC ROSNEFTEGAZ2 following the results of sale of Rosneft shares. A total of around $\mathrm{Rb} 1$ trillion and $20 \mathrm{bn}^{3}$ of federal budget revenues are expected to be generated.

1 A long-lasting lawsuit with the Federal Agency for State Property Management which concerns the ownership of a few buildings and structures, ill-defined ownership structure leaked out in connection with the provision of transport security.

2 The head of the Ministry of Finance of Russia said at the aforementioned meeting of the Russian Government that he was not sure if it would be possible to generate this amount from the company.

3 However, the addition of revenues from the specified channels makes up an amount which is Rb 10bn less. The difference 
Furthermore, the materials of the meeting also refer to a sum of $\mathrm{Rb} 1,7$ trillion as the amount generated from sale of JSCs' shares in 2013-2016. Therefore, it is not quite clear how this amount corresponds to the previous amount of revenues.

Assuming that the sum simply contains privatization revenues of the current year, they should amount to around $\mathrm{Rb} 680 \mathrm{bn}$, thereby exceeding direct budget revenues from privatization over the next three years. This is very doubtful, the more so, because $\mathrm{Rb} 1,7$ trillion are linked to a 3-year time horizon in other context. It may, therefore, be suggested that the difference between the values is a part of the monies generated from sale of largest companies which are supposed to be spent to develop these companies and increase their capital, but the program lacks respective numerical benchmarks.

Possible allocation of revenues from privatization of ALROSA shares (subject to coordination of sale of the interest held by the regions and municipalities) for the development of infrastructure in the Republic of Sakha Yakutia, without specifying scales and proportions which would rather promote smaller budget revenues, should be considered in the same context.

It is very difficult to speak about whether or not the declared goals can be achieved, bearing in mind the amount of federal budget revenues from privatization, because it depends both on the list and value of assets proposed for sale and stock market conditions which depend largely on the current macroeconomic situation.

With regard to the place and role of revenues from privatization within the frameworks of budget process in drafting a new 3-year budget, the Ministry of Finance of Russia took account of a total of Rb 925,9bn ( $\mathrm{Rb} 230,8$ bn in 2014, Rb 445,1bn in 2015, Rb 250bn in 2016) of revenues from sale of the federally-held interest in joint-stock companies over three years in basic parameters of the federal budget for 2014-2016.

According to the Russian finance department, shortfall in revenues from privatization may be replaced with oil and gas revenues with possible reduction in contributions to the Reserve Fund in the current year. A similar procedure, with a different wording though, was allowed through amendments to the two previous federal budgets for 2011 and the planning period of 2012 and 2013, and for 2012 and the planning period of 2013 and 2014, when oil and gas revenues generated beyond a specific value might be used for the replacement of state borrowings and/or revenues from sale of state-held interest and other types of stakeholding, or for other purposes established by the law.

exceeds the single value of revenues from privatization ( $\mathrm{Rb} 3 \mathrm{bn}$ annually within the period of 2014 thru 2016) which is officially declared in the new privatization program.
In this respect, it is to be recalled that neither the main part nor the annexes relating to sources of financing of federal budget deficit, where inter alia there is only a general item on other sources without any specifics, of the applicable Federal Law dated December 3, 2012, No. 216-FZ "On the Federal Budget in 2013 and the Planning Period of 2014 and 2015" contain any information on a particular value of revenues from privatization ${ }^{1}$. Nothing new was contributed in this context by the recent amendments to the 3-year budget by the Federal Law dated June 7, 2012, No. 133-FZ.

According to the Report on the Implementation of the Federal Budget as of June 1, 2013 (according to sources of internal financing of deficit), posted on Federal Treasury's official website, revenues from sale of a federally-held interest and other types of stakeholding amounted to $\mathrm{Rb} 17227,3 \mathrm{~m}$ (no target value for the year was specified).

The recently established budget process mechanism, when the text of a newly adopted budget law contains no indications on privatization in the context of budget revenues, leaves a wide and unlimited scope for any decisions that can be made on the list of privatized assets, including terms and sale format of such assets. All the more so, as the existing privatization program clearly shows that many amendments and updates with regard to a newly adopted similar document are very likely to be made.

A total of 45 respective legal acts and regulations, of which 9 were released in 2013, 24 in 2012, 11 in 2011 (one was published as early as the very end of 2010), have been adopted under the Russian Government Executive Order dated November 27, 2010, No. 2102-r as of the mid-July 2013 since the adoption of the Privatization of Federal Property and the Main Guidelines for the Privatization of Federal Property in 2011-2013.

In general, the new privatization program looks more moderate and substantiated, given retained public corporate control of a series of companies regarded as natural monopoly and infrastructure entities involved in capital-intensive types of activity with long payback periods, playing a major role in realization of the structural and industrial policy, who acted as public agents in taking crisis response measures during the acute phase of the crisis of 2008-2009.

1 However, the explanatory note to the Draft Law "On the Federal Budget in 2013 and the Planning Period of 2014 and 2015" pointed out to a possibility of using a part of extra oil and gas revenues to replace sources of financing of federal budget deficit by the decision of the Russian Government in building up the Reserve Funds and the National Wealth Fund. 